subject for examination are recommended to read that part of Roscoe's "Lessons in Elementary Chemistry" which treats of Inorganic Chemistry (pp. 1-268, new edition, I 869). The practical examination will be in the following subjects as treated of in Harcourt and Madan's "Exercises in Practical Chemistry":-I. The preparation and examination of gases (pp. 59-107);2. The qualitative analysis of single substances (pp. 247-300; see also sections IV. and V., omitting that which relates to substances or properties of substances not referred to in the Analytical Course). (4.) The Elements of Physics. Candidates offering themselves for examination in this subject will be expected to show an acquaintance with Part I., together with any two of Parts II., III., IV. of the following treatise ;- "Elementary Treatise on Natural Philosophy," by Deschanel. Translated and edited by Prof. Everett. Part I. Mechanics, Hydrostatics, and Pneumatics. Part II. Heat. Part III. Electricity and Magnetism, of which chapter 39 may be omitted. Part IV. Light and Sound (which will be published in a few weeks .

\section{THE MURCHISON CHAIR OF GEOLOGY}

UPWARDS of a year ago we duly chronicled the founding of a chair of geology and mineralogy in the University of Edinburgh by Sir Roderick Murchison, and we augured that the munificence of the founder would not be long in bearing fruit. It is pleasant to learn that the first session has been concluded successfully, and that the class has been greatly larger than the most sanguine friends of geolngy in Scotland had anticipated. In addition to the ordinary lectures of the class-room, there have been frequent afternoon excursions to the field, where the principles of the science have been learnt in a way in which they cannot be from mere lectures or books. Edinburgh is peculiarly favoured by nature for instruction of this practical kind. The crags and ravines which surround, or even stand in the midst of, the streets and gardens furnish admirable models of many of the more important and striking facts of physical geology. These advantages have been fully made use of during the past winter and spring. There has been, we are told, a brisk sale of geological hammers, and bands of hammerers have been seen on Saturday afternoons wandering over hillside and quarry. At the close of the session Prof. Geikie and his students celebrated the termination of their labours together by a week's holiday in the island of Arran. For such an excursion good weather is the first grand essential, and in this respect the party appears to have been singularly lucky. The days were bright and bracing, so that from the highest hill tops the eye could wander over all the wide expanse of firth and fell which lies between the mountains of Jura and the far-off faintlyseen uplands of Galloway.

It was chiefly to the northern half of the island that the attention of the excursionists was devoted. They traced, of course, the well-known and often-described features-the granite mountains and veins, the schists, the rrap-dykes, the carboniferous sandstones, conglomerates, limestones and tuffs, the raised beaches, \&c. But they noted some points which deserve, perhaps, more special remark than has yet been accorded to them, and of these we have been furnished with the following jottings :-

I. Some interesting observations were made on the relation between the joints of the granite and the forms of surface into which that rock has been wasted. Everybody who has seen the Arran mountains remembers their sharp serrated ridges and deep corries. It was noticed in all the examples which were visited that each knifeedged crest coincided with the intersection of two sets of joints dipping in opposite directions, as the ridge of a roof coincides with the line along which the two opposite slopes meet. Where the one set of joints differed most in angle of inclination from the other, there was seen to be a corresponding difference in the slope on two sides of the crest, the highly inclined joints having a steep face, sometimes quite a precipice, on their side, while the less inclined joints had a gentler declivity on the other. From the summits it seemed as if the changes in the direction and inclination of the granite ridges were largely due to changes in the trend and slope of the systems of crossjoints. But there was not time to work out this problem.

2. Some mineralogical and petrographical facts of interest were gleaned. The passage of the Arran pitchstone was traced into a dull pearlstone which appeared to be closely connected with, if, indeed, it did not pass into one of the pale compact felstones or "compact felspars." The common association of pitchstone with the tertiary vol. canic rocks of the west coast, and its entire absence from any cf the abundant palæozoic volcanic masses of the mainland, raises the suspicion that perhaps the Arran pitchstones are likewise of tertiary date. The association of these pitchstones with some of the characteristic felstones or porphyries of that island also suggests as late an origin for the latter. Some facts, indeed, were noted, which, if properly worked out, might throw light on this question. It was observed, for example, that in the picturesque columnar ridge above Corriegills the columns are so arranged as to indicate that the mass of rock flowed along and consolidated in a trough or hollow. Was this hollow a valley carved out of the denuded surface of the carboniferous rocks, and did the porphyry flow into it as a coulée? A phenomenon of rare occurrence was noted in this Corriegills porphyry. Usually the quartz in such rocks exis:s merely as irregularly-shaped blebs or grains. In this rock, however, it is crystallised, and frequently appears in little doubly-terminated pyramids. Some of the party spent half an hour in gathering up perfect crystals from the weathered hollows of the rock. These crystals do not occur in amygdaloidal cavities but as essential constituents of the rock. In the Goatfell granite some cavities were found with well crystallised quartz, and one of the party was fortunate enough to light upon one cavity from which he obtained a handful of small cairngorms.

3. The moraines of the Glen Cloy afforded a pleasant afternoon. It was matter for surprise to some of the party that amid all that has been written about Arran these truly remarkable moraines have not received more notice. It is true, they do not lie among the group of the higher mountains of the island, and they have not the magnificent setting around them which they would have had if they had stood in Glen Rosa, or Glen Sannox, or Glen Iorsa. But in none of these glens, even though they plunge into the very heart of the central mass of granite, is there anything in the way of moraines at all to compare with the huge concentric mounds of rock-rubbish, cumbered with blocks, which roughen the bottom and sides of the deep recess in which the upper part of Glen Cloy terminates. The plateau which served as the snowfield whence the Glen Cloy glacier was fed rises to an average height of only about $I, 400$ or $I, 500$ feet above the sea, while the neighbouring granite peaks are about twice as high. Yet the higher granite mountains have afforded comparatively few and small moraines. It gives a good notion of the severity of the climate during the glacial period to refiect that the little isolated patch of elevated ground, forming now the island of Arran, was large enough to nourish, even on its lower plateaux, snow-fields and glaciers.

4. Many striking lessons were learnt regarding some of the broad aspects of atmospheric denudation. Particularly were these lessons brought home to the mind among the wasted crags and corries of the granite mountains. Granite which, in the popular creed, is regarded as one of the most imperishable of rocks, was seen to be covered 
with acre upon acre of its own wasted débris. On the crests of the heights the rock was found to be split by frosts along its joints ; numberless blocks had fallen off, and the slopes below were thickly strewn with them. On smoother declivities, such as those that descend from the lonely and barren Beinn Bharrain, each casual torrent was seen to have ploughed out of the loosened and corroded granite a deep trench, which in time might get widened and deepened into a lateral valley. The waste of mountains could not be more eloquently revealed. As the party in long file threaded its way through these solitudes, a feeling which had been growing all day found at last expression, and as the scattered scouts who, in the exuberance of young life, had dispersed up and down hill on either side of the main body, gathered together into one merry company at the edge of the dark and lonely Corrie au Lachan, it was unanimously agreed that had this band of stone-breakers seen nothing more than these proofs of how a mountain may be sculptured, the lesson was worth all the trouble and fatigue of the excursion.

\section{NÖE'S THERMO-ELECTRIC BATTERY}

A

SUPPLY of dynamic electricity is almost as requisite now for the lecture table as the supply of gas or water. The decomposition of water and various other liquids, the decomposition of certain gases in Hoffmann's $U$ tube, with the aid of Rhumkorff's coil, and the physical test afforded by the passage of electricity through vacua containing traces of different gases, are most constant lecture experiments. And no wonder: the brilliant purple light afforded by the passage of electricity through a nitrogen vacuum, is, perhaps, the best and most reliable, if, indeed, it be not the only, test for nitrogen gas ; while the decomposition of water gas, of ammonia, and of marsh gas, are experiments of the utmost importance in modern Chemistry. Hitherto the chief drawback has been the voltaic battery ; the setting up of the battery before the lecture, the taking it to pieces afterwards, the constant amalgamation of the zinc plates, the consumption of zinc and acid, the fumes-in a word, the general inconvenience inseparable from any form of voltaic battery, but reduced to a minimum in Sir William Thomson's constant gravitation battery. The former of these inconveniences are more apparent, when, as is often the case, the battery is only required for five minutes during the whole lecture.

Hence, when a statement recently appeared in Poggendorff's "Annalen," to the effect that a thermo-electric battery of great power had recently been constructed in Vienna by Franz Noë, we were glad to take the first opportunity of trying to what extent it could replace the ordinary voltaic battery for the lecture table. It was stated that the battery could readily decompose water, work a Rhumkorff's coil, and powerfully excite electro-magnets. As we understand from the maker that the battery about to be described is the only one in use in this country, it may be of interest to give a short account of its capabilities.

The battery consists of eighty elements, which are heated by eighty small Bunsen burners, the cooling of the opposite extremities being effected by broad, blackened sheets of copper, which of course radiate freely. The negative metal is a silver-white alloy drawn into wire, and partially enclosed in small copper cylinders to protect it from the direct action of the flame. The positive metal is a dull grey alloy extremely crystalline and brittle, and is cast into cylinders abont $20 \mathrm{~mm}$. long by $7 \mathrm{~mm}$. diameter. The composition of both these alloys is kept secret. Alternate pairs are separated by small square plates of mica. The elements can with readiness be combined either for quantity or intensity. Thus the eighty elements may be used together in one series, or in two series of forty elements, or in four serics of twenty elements.
The battery under consideration differs somewhat from that described in Poggendorff; it is larger; a sliding double groove keeps the burners in one position, exactly midway between the double rows of elements; and arrangements have been introduced in order to prevent radiation from the sides of the flames to the blackened copper radiators, that is, to the cool end of the elements.

According to the maker, the battery is equal to " 8 grosse Daniell'sche Elemente." The electromotive force of one element, according to M. Von Waltenhofen, was found to be equal to I'24 to I'36 Jacobi-Siemens's unit, while a Daniell's cell (no dimensions given) is equal to twelve of these units. One Noë's elements is said to be equal to I I of the ordinary bismuth-antimony elements.

On testing the battery of eighty elements, we found it to be somewhat weaker than we expected. It is, however, very difficult to know to what extent the elements may be safely heated. No definite directions are given on the subject by the maker, and as the composition of the alloys is kept secret, one is unable to ascertain their fusing point without sacrificing a pair of elements.

With large iron electrodes placed in a solution of very dilute potash, water was decomposed by the battery at the rate of 22 cub. centimetres per minute. With small platinum electrodes exposing less than one square centimetre of surface in water rendered acid by dilute sulphuric acid, Io cc. of the mixed gases were evolved per minute. One of Gaiffe's induction coils, capable of giving a spark I $5 \mathrm{~mm}$. long, was connected with the battery. A copious stream of sparks I I $\mathrm{mm}$. long was produced. With a small 6-inch electro-magnet, surrounded by only two coils of wire, the battery produced a portative force of more than 2olbs., when the gas was turned down so as to be nearly level with the orifice of the burners, and the flame was distant some $9 \mathrm{~mm}$. from the surface of the elements. It is very possible that the battery might be heated to a higher temperature than that employed for decomposing water without detriment. In no case did the upper cylin. ders glow with even a faint red heat.

Here then we have an instrument which at a moment's notice can be set in action, which consumes a small amount of gas, is tolerably portable, and which is sufficient for all ordinary electro-magnetic experiments, for lecture demonstration of the decomposition of water, ammonia, \&c., and for many purposes for which a voltaic battery has now to be used. Four or six of these batteries would be sufficient for all purposes gave the electric light ; they might be made more compact, and could with ease be placed beneath and at one end of the lecture table. The lighting of a row of gas jets would thus furnish us at any moment with an abundant current of electricity. The battery is, indeed, less strong than one could wish, but the production of it is a step in the right direction; and we look forward to the time when powerful and compact thermo-electric batteries will be found in every lectureroom, and when the lighting of a row of gas jets will, through the medium of such batteries, furnish us at any moment with a powerful electric light.

We are at the outset of invention in this direction; several improvements in Noë's battery seem to us to be both advisable and practicable. Let the elements be enlarged, the brittle cylinders of alloy protected, the radiation of heat from the sides of the row of gas jets to the cool ends of the elements entirely prevented, which is by no means the case now ; and, if possible, let a current of cold water flow through pipes interspersed among the cooling plates. Again, let the pressure and amount of gas be indicated, and let the stop-cock admitting the gas be furnished with a projecting pin, moving on a graduated dial, so that any desired amount of gas (pre-determined) can at any time be caused to issue from the burners, and thus any desired strength of current (pre-determined in reference to the heating effect by ordinary electrometrical means) be obtained. G. F. RODWELI, 